\title{
PENGARUH PENGGUNAAN MULTIMEDIA PRESENTASI BERBASIS PREZI DAN GAYA BELAJAR TERHADAP KEMAMPUAN MENGINGAT KONSEP
}

\author{
Muh. Rais \\ Jurusan Pendidikan Teknik Mesin Fakultas Teknik Universitas Negeri Makassar \\ Email: raismisi@gmail.com
}

\begin{abstract}
Abstrak
Pengaruh penggunaan multimedia presentasi berbasis prezi dan gaya belajar terhadap kemampuan mengingat konsep Penelitian ini bertujuan untuk: 1) menjelaskan perbedaan kemampuan mengingat konsep obyek antara mahasiswa yang dibelajarkan dengan menggunakan multimedia presentasi prezi desktop dan mahasiswa yang dibelajarkan dengan menggunakan multimedia presentasi power point, 2) menjelaskan perbedaan kemampuan mengingat konsep obyek antara mahasiswa yang belajar dengan gaya belajar visual, gaya belajar auditori, dan gaya belajar kinestetik, dan 3) menjelaskan pengaruh interaksi antara multimedia presentasi (prezi desktop dan power ponit) dengan gaya belajar (visual, auditori, dan kinestetik) terhadap kemampuan mengingat konsep obyek. Penelitian ini menggunakan rancangan quasi eksperimen menggunakan versi nonequivalent control group design faktorial $2 \times 3$. Subjek penelitian sebanyak 105 orang (52 kelompok kontrol dan 53 kelompok eksperimen. Data dianalisis dengan menggunakan teknik uji-t. Hasil penelitian menunjukkan:1) terdapat perbedaan kemampuan mengingat konsep mata kuliah multimedia pembelajaran antara kelompok mahasiswa yang dibelajarkan menggunakan multimedia pembelajaran presentasi prezi desktop dengan kelompok mahasiswa yang dibelajarkan menggunakan multimedia pembelajaran presentasi power point pada mahasiswa Jurusan Pendidikan Teknologi Pertanian Fakultas Teknik UNM dengan nilai F = 39.251 yang lebih besar dari nilai $F$ tabel $=3.92$. 2) terdapat perbedaan kemampuan mengingat konsep mata kuliah multimedia pembelajaran antara kelompok mahasiswa yang memiliki gaya belajar visual, auditori dan kinestetik pada mahasiswa Jurusan Pendidikan Teknologi Pertanian Fakultas Teknik UNM dengan nilai $F=31.482$ yang lebih besar dari nilai $F$ tabel $=3.92,3)$ tidak ada interaksi antara multimedia pembelajaran dan gaya belajar (visual, auditori dan kinestetik) terhadap kemampuan mengingat konsep mata kuliah multimedia pembelajaran mahasiswa Jurusan Pendidikan Teknologi Pertanian Fakultas Teknik UNM dengan nilai $F=3.870$ yang lebih kecil dari nilai $F$ tabel $=3.92$.
\end{abstract}

Kata Kunci : Multimedia Prezi, Gaya Belajar, Mengingat Konsep

\begin{abstract}
The effect of use multimedia presentation based prezi and Learning styles to the ability to remember of concept. This study aims to: 1) explain differences in the ability to remember the concept of the object of the students who learned with a multimedia presentation using Prezi desktop and students who learned with multimedia presentations using power point, 2) explain the differences in the ability to remember the concept of object between students studying with a visual learning style, learning styles auditory, and kinesthetic learning styles, and 3) describes the effect of the interaction between a multimedia presentation (Prezi desktop and power ponit) learning styles (visual, auditory, and kinesthetic) to the ability to remember the concept of object. This study used a quasi-experimental design using a nonequivalent control group version $2 \times 3$ factorial. Research subjects were 105 persons (52 controls and 53 experimental groups. Data were analyzed using $t$-test techniques. The results showed: 1) there are differences in the ability to remember the concept of multimedia learning courses among the group of students that learned using learning multimedia presentations with Prezi Desktop student group that learned to use multimedia learning power point presentation on the students of Department of Agricultural Technology, Faculty of Engineering Education UNM with $F=39251$ value greater than the value of $F$ table $=3.92 .2$ )
\end{abstract}


there are differences in the ability to remember the concept of multimedia learning courses among a group of students who have learning styles are visual, auditory and kinesthetic the students of Department of Agricultural Technology, Faculty of Engineering Education UNM with a value of $F$ $=31482$ greater than the value of $F$ table $=3.92$, 3) no there is interaction between the multimedia learning and learning styles (visual, auditory and kinesthetic) on the ability to remember the concept of multimedia learning courses students from the Department of Education of Agricultural Technology, Faculty of Engineering at UNM with the value F=3,870 less than the value of $F$ table $=3.92$.

Keywords:: Multimedia Prezi, Learning Style, Remember of Concept

\section{PENDAHULUAN}

Pengaruh penggunaan multimedia dalam pembelajaran secara empiris telah banyak diteliti dan hasilnya adalah memberikan pengaruh yang positif dalam pembentukan pengetahuan. Beberapa bukti secara empiris terkait penerapan multimedia dalam pembelajaran adalah eksperimen Prasetya, dkk (2008) terhadap 78 siswa yang menggunakan media berbasis komputer dengan pendekatan chemo-edutainment (CET) sebagai media pembelajaran. Hasil eksperimen menunjukkan bahwa skor rata-rata hasil belajar kimia sebesar 75,79 dari hasil. Dari skor tersebut dapat dilihat bahwa kelas eksperimen tersebut mengalami peningkatan nilai rata-rata hasil belajar. Hal ini dikarenakan media pembelajaran yang ditampilkan menampilkan sesuatu yang berbeda dengan pembelajaran konvensional yaitu dengan memasukan unsur-unsur yang menghibur seperti tampilan animasianimasi dan juga dilengkapi dengan musik latar belakang tampilan media.

$$
\text { Penelitian Mayasari }
$$

terhadap 36 siswa SMA di Pontianak menunjukkan bahwa terdapat perbedaan prestasi belajar berupa kemampuan mengenali konsep dan objek sebelum dan sesudah diajarkan dengan menggunakan bahan ajar ikonik melalui penggunaan multimedia pembelajaran. Dalam penelitian tersebut ditemukan kontribusi penggunaan multimedia pembelajaran interaktif berhasil membantu memfasilitasi kesulitan belajar siswa dalam memahami konsep-konsep dan prosedur belajar kimia.

Penggunaan multimedia dalam praktek pembelajaran sudah berkembang secara inovatif. Salah satu sebabnya karena kuatnya pengaruh multimemedia dalam membantu mengkonsepsi pengetahuan pada pebelajar. Menurut Mayer (2009) penambahan jenis gambar tertentu pada kata-kata dapat membantu pebelajar memahami pesan-pesan instruksional. Pendapat ini didukung oleh Rieber (1999), bahwa dalam kondisi tertentu pebelajar dapat belajar lebih baik dengan perolehan retensi dan ransfer informasi yang baik jika penggunaan media pembelajaran berbasis komputer dengan menambahkan hukum-hukum gerak dan grafik beranimasi di dalamnya. Dalam konteks ini, media yang dimaksud adalah media untuk komunikasi dan sumber informasi dalam belajar (Smaldino, Russel, Heinich, \& Molenda, 2005)

Gaya belajar sebagai ciri karakteristik pebelajar yang memberikan arah dalam mengolah informasi berdasarkan strategi kognitif diduga memberi pengaruh dalam retensi hasil belajar. Selain faktor metode belajar, gaya belajar sebagai faktor karakteristik pebelajar. Menurut Gunawan (2004), gaya belajar adalah cara yang lebih kita sukai dalam melakukan kegiatan berpikir, memproses dan mengerti suatu informasi. Cara ini diduga memberikan pengaruh 
dalam membentuk pengetahuan pebelajar baik dalam hal mengingat, memahami, maupun mengaplikasikan pengetahuan tertentu.

Menurut Hofstetter dalam Munir (2013), multimedia berarti penggunaan komputer untuk menyajikan dan menggabungkan teks, suara, gambar, animasi dan video dengan alat bantu (tool) dan koneksi (link), sehingga pengguna dapat melakukan navigasi, berinteraksi, berkarya, dan berkomunikasi. Mayer (2009) mendefinisikan multimedia pembelajaran sebagai presentasi materi dengan menggunakan kata-kata sekaligus gambar-gambar. Kata-kata yang dimaksud adalah dalam bentuk informasi verbal dan gambar-gambar adalah grafik yang statis maupun beranimasi atau video. Multimedia pembelajaran dalam penelitian ini memfokuskan kajian pada penggunaan teks, grafik, gambar, tabel, video yang terintegrasi kedalam aplikasi media presentasi berbasis komputer. Aplikasi ini menggunakan media presentasi prezi desktop.

Prezi adalah sebuah perangkat lunak untuk presentasi berbasis internet. Selain untuk presentasi, Prezi juga dapat digunakan sebagai alat untuk mengeksplorasi dan berbagi ide di atas kanvas virtual. Prezi menjadi unggul karena program ini menggunakan Zooming User Interface (ZUI), yang memungkinkan pengguna Prezi untuk memperbesar dan memperkecil tampilan media presentasi (Enterprise, 2012) . Prezi digunakan sebagai alat untuk membuat presentasi dalam bentuk linier maupun non-linier, yaitu presentasi terstruktur sebagai contoh dari presentasi linier, atau presentasi berbentuk petapikiran (mind-map). Pada Prezi, teks, gambar, video, dan media presentasi lainnya ditempatkan di atas kanvas presentasi, dan dapat dikelompokkan dalam bingkai-bingkai yang telah disediakan. Pengguna kemudian menentukan ukuran relatif dan posisi antara semua obyek presentasi dan dapat mengitari serta menyorot obyek-obyek tersebut. Untuk membuat presentasi linier, pengguna dapat membangun jalur navigasi presentasi yang telah ditentukan sebelumnya.

Prezi pada awalnya dikembangkan oleh arsitek Hungaria bernama Adam Somlai-Fischer sebagai alat visualisasi arsitektur. Misi yang dinyatakan oleh Prezi adalah untuk "membuat berbagi ide menjadi lebih menarik", dan Prezi sengaja dibuat untuk menjadi alat untuk mengembangkan dan berbagi ide dalam bentuk visual yang bersifat naratif.

Presentasi adalah sebuah show dari satu atau beberapa tampilan yang ditonton dan diharapkan memberikan pengaruh untuk memberikan fokus perhatian dari audiens. Kusrianto (2013) menegaskan bahwa komunikasi secara visual dalam bentuk signal-signal yang disampaikan secara non verbal, 93\% dapat mencapai sasaran, yakni pemahaman diterima oleh audiens. Pengertian isyarat non verbal yang dimaksud adalah berupa bahasa gambar yang mampu mengembangkan imajinasi audiens lebih dalam dan lebih luas dibanding pesan verbal, baik berupa auditori maupun pesan teks. Intinya bahwa teks lebih bersifat pasti dan terbatas pada satu definisi, sementara gambar dapat memberi peluang multi interpretasi tanpa batas.

Presentasi Power Point dan presentasi Prezi memiliki perbedaan yang mendasar. Power Point menggunakan presentasi secara lurus, linear dari awal hingga akhir slide. Paparan disajikan secara berurutan dari slide satu, dua hingga berakhir. Sedangkan pada presentasi Prezi, tidak menggunakan istilah slide. Menurut Enterprise (2012), slide pada Prezi digantikan oleh media tampilan kamvas yang berukuran besar, yang dapat diedit secara bebas, dizoom untuk mendapatkan bagian-bagian yang 
dipresentasikan. Prezi sebagai media presentasi Non-Linear dapat mengarahkan tampilan penyajian dari berbagai arah sesuai yang dikehendaki, artinya presentasi dapat dilakukan dari section mana saja yang diinginkan.

Belajar merupakan suatu kegiatan yang berproses dan terus mengalami suatu perubahan dan kemajuan kepada hal-hal yang positif. DePorter dkk. (2002) mengemukakan bahwa belajar adalah tempat yang mengalir, dinamis, penuh resiko, dan menggairahkan. Witkin (1981) berpendapat proses belajar selalu berlangsung dalam tiga tahapan, yaitu; (1) acquisition (tahap perolehan/penerimaan informasi); (2) storage (tahap penyimpanan informasi); dan (3) retrieval (tahap mendapatkan kembali informasi). Dalam belajar seseorang memili cara untuk mengolah informasi yang oleh DePorter \& Hernacki (2004) disebut sebagai gaya belajar. Menurutnya, gaya belajar merupakan kombinasi bagaimana seseorang dapat menyerap, kemudian mengatur dan mengolah informasi. Pada awal pengalaman belajar, salah satu indikator yang harus dikenali adalah gaya belajar seseorang. Ini dikarenakan gaya belajar terindikasi memiliki pengaruh terhadap pencapaian hasil belajar.

Supaya pembelajaran efektif atau berhasil, tentunya banyak yang perlu dilakukan oleh dosen. Salah satunya adalah mencoba memahami gaya belajar (learning style) mahasiswa. Sebagai contoh, jika kita cenderung mengajar secara verbal melulu, sedangkan pebelajar lebih mudah menerima secara visual, misalnya, maka jangan berharap bahwa pembelajaran akan efektif. Definisi gaya belajar oleh Felder \& Brent (2005), dikatakan sebagai cara seseorang memahami dan memproses informasi baru, memperoleh pengalaman belajar baru, dan/atau memecahkan suatu masalah.
DePorter \& Hernacki (2004) membagi tiga jenis gaya belajar berdasarkan pada aspek penglihatan, pendengaran, dan gerak. Dalam istilah selanjutnya disebut modalitas belajar berdasarkan tiga jenis gaya belajar yang dikenal dengan istilah visual, auditori, dan kinestetik (VAK). Gaya belajar visual memfokuskan pengolahan informasi melalui gambar atau visualisasi. Seseorang yang diduga kuat menganut gaya belajar ini akan lebih mudah memahami ide dan informasi untuk diolah menjadi pengetahuan baru yang terbentuk dan disimpan dalam memori jangka pendek maupun memori jangka panjang. Menurut DePorter \& Hernacki (2004) seseorang dalam menjelaskan sesuatu kepada orang yang memiliki kecenderungan gaya belajar visual, akan menciptakan gambaran mental tentang apa yang dijelaskan oleh orang tersebut.

Gaya belajar auditori memungkinkan seseorang belajar dengan mengandalkan transformasi pengetahuan melalui kemampuan mendengar. Ketika informasi diperoleh melalui mendengar, lalui diteruskan melalui ingatan dan pemahaman hingga terbentuk pengetahuan baru. Seseorang yang dominan dalam gaya belajar anak menurut DePorter \& Hernacki (2004) benar-benar menempatkan pendengaran sebagi alat utama menyerap informasi atau pengetahuan untuk mengingat dan memahami informasi yang diterima. Gaya belajar kinestetik menurut DePorter \& Hernacki (2004) lebih memfokuskan pada cara belajar seseorang yang diperoleh melalui pengalaman melakukan langsung.

Anderson \& Krathwohl (2010) melihat gaya belajar sebagai proses memilih, mengorganisasikan, dan mengontrol strategi-strategi belajar. Strategi-strategi belajar ini meliputi strategi-strategi kognitif dalam menghaf, mengelaborasi, mengorganisasikan, dan 
mengingat materi pembelajaran. Kemampuan mengingat merupakan proses mental kognitif yang bekerja dalam mengambil pengetahuan yang dibutuhkan dari memori jangka panjang (long term memory) (Anderson \& Krathwohl, 2010). Pengetahuan mengingat sangat dibutuhkan untuk mengembangkan proses belajar bermakna, menyelesaikan masalah dan mengembangkan pengetahuan ke tingkat pemahaman dan aplikasi. Pengetahuan mengingat membantu pebelajar dalam mengkonstruksi pengetahuan baru sebagai proses strategi kognitif.

Memandang bahwa multimedia pembelajaran khususnya multimedia presentasi prezi dan power point dan gaya belajar sebagai variabel karakteristik pebelajar, diduga kuat mempengaruhi hasil belajar, khususnya dalam hal kemampuan mengkonsepsi pengetahuan. Hal ini mendorong perlunya dilakukan penelitian dengan melihat sejauh mana efek dari kedua variabel mempengaruhi kemampuan mengingat konsep pada mata kuliah multimedia pembelajaran.

\section{METODE PENELITIAN}

Penelitian ini menggunakan rancangan quasi eksperimen. Penelitian quasi experimental dengan versi desain nonequivalent control group design (the version of nonequivalent control group design) (Tuckman, 1999) faktorial 2x3, berusaha mencari keterkaitan hubungan suatu variabel tertentu (Vockell \& Asher, 1995; Gall, 2003; Salkind, 2006). Dalam penelitian ini semua kelompok mendapat perlakuan, yakni kelompok pertama menggunakan multimedia presentasi berbasis prezi dan kelompok kedua menggunakan multimedia presentasi power point.

Subjek dalam penelitian ini adalah mahasiswa program studi Pendidikan Teknologi Pertanian FT Universitas Negeri Makassar yang berada pada semester IV tahun akademik 2013-2014. Jumlah keseluruhan berdasarkan data program studi adalah kelas A sebanyak 52 orang dan kelas B sebanyak 53 orang. Jumlah keseluruhan subjek adalah 105 orang. Penentuan penempatan subjek sebagian sebagai kelompok eksperimen dan sebagian sebagai kelompok kontrol didasarkan pada ciri kuasi eksperimen yang menempatkan subjek tidak secara acak dengan kata lain subjek sudah terbentuk berdasarkan kelas yang sudah ada (Salkind, 2006). Berdasar pada ciri tersebut, maka subjek yang terdiri dari dua kelas yang sudah terbentuk dapat langsung digunakan sebagai kelas eksperimen dan kelas kontrol. Dalam hal ini kelas A PTP 2013 yang berjumlah 53 orang ditempatkan sebagai kelas eksperimen dan kelas B PTP 2013 yang berjumlah 52 orang ditempatkan sebagai kelas kontrol.

\section{Prosedur Penelitian}

Instrumen yang digunakan dalam penelitian ini dikelompokkan menjadi dua jenis, yaitu (1) instrumen untuk mengukur gaya belajar dan (2) instrumen untuk mengukur kemampuan mengingat konsep matakuliah multimedia pembelajaran. Kedua instrumen tersebut berupa suatu tes. Pemilihan suatu tes sebagai instrumen dalam penelitian perlu dijelaskan dasar pertimbangannya. Dasar pertimbangan pemilihan tes perlu dijelaskan sebagai berikut: Instrumen pertama menggunakan instrumen gaya belajar VAK (DePorter \& Hernacki, 2004). Tes ini digunakan untuk mengukur kemampuan individu pebelajar dalam mengingat konsep berdasarkan tiga gaya belajar, visual, auditori, dan kinestetik. Instrumen untuk mengukur hasil belajar matakuliah multimedia pembelajaran berupa tes untuk mengukur kemampuan mengingat konsep.

Data dikumpulkan melalui langkahlangkah sebagai berikut: 1) memberikan tes gaya belajar model VAK, 2) 
memberikan pre-test, 3) melaksanakan pembelajaran (eksperimen) dengan pendekatan multimedia presentasi dan 4) memberikan postest pada mahasiswa.

Uji persyaratan analisis digunakan uji normalitas data dan uji homogenitas varian. Uji normalitas data menggunakan teknik Kolmogorov-Smirnov dan uji homogenitas varian menggunakan levene test. Uji normalitas data dan uji homogenitas data dimaksudkan untuk memenuhi asumsi-asumsi keparametrikan. Asumsi-asumsi keparametrikan tersebut adalah 1) sampel harus berasal dari populasi yang terdistribusikan atau tersebar secara normal, 2) nilai-nilai varian dalam kelompok-kelompok sampel harus homogen, 3) data yang harus diolah harus berskala interval atau rasio, dan 4) sampel penelitian harus diambil secara random (Winarsunu, 2006: Sugiyono, 2008).
Analisis data dalam menguji hipotesis penelitian menggunakan analisis statistik parametrik, dengan teknik analisis Anova (analisys of variance) dua jalur (Gall, 2003). Analisis varian faktorial $3 \times 2$ digunakan untuk menguji hipotesis penelitian. Anava faktorial atau anava ganda merupakan teknik statistik parametrik yang digunakan untuk menguji perbedaan antara kelompok-kelompok data yang berasal dari dua variabel bebas atau lebih. (Winarsunu, 2006). Pengujian hipotesis nihil $\left(\mathrm{H}_{0}\right)$ dilakukan pada taraf signifikansi $5 \%$ atau $\alpha=0,05$. Untuk menguji hipotesis penelitian digunakan bantuan SPSS 20,00 for windows.

\section{HASIL}

Deskripsi Dimensi Gaya Belajar

Data hasil pengukuran gaya belajar berdasarkan instrument VAK disajikan dalam Tabel 1 berikut:

Tabel 1: Deskripdi Gaya Belajar

\begin{tabular}{cccc}
\hline & $\begin{array}{c}\text { Multimedia } \\
\text { Prezi }\end{array}$ & $\begin{array}{c}\text { Multimedia } \\
\text { Power Point }\end{array}$ & Jumlah \\
\hline Visual & 11 & 17 & 28 \\
\hline Auditori & 20 & 14 & 34 \\
\hline Kinestetik & 21 & 22 & 43 \\
\hline Jumlah & $\mathbf{5 2}$ & $\mathbf{5 3}$ & $\mathbf{1 0 5}$ \\
\hline
\end{tabular}

Data hasil posttest kedua kelompok mahasiswa yang dibelajarkan dengan dua jenis multimedia disajikan dalam Tabel 2 berikut:

Tabel 2: Deskripsi Kemampuan Mengingat Konsep

\begin{tabular}{ccccc}
\hline $\begin{array}{c}\text { Multimedia } \\
\text { Pembelajaran }\end{array}$ & $\begin{array}{c}\text { Gaya } \\
\text { Belajar }\end{array}$ & $\begin{array}{c}\text { Mean } \\
(\mathbf{M})\end{array}$ & $\begin{array}{c}\text { Standar } \\
\text { Deviation }\end{array}$ & $\mathbf{N}$ \\
\hline $\begin{array}{c}\text { Multimedia } \\
\text { Prezi }\end{array}$ & Visual & $\begin{array}{c}43,6 \\
250\end{array}$ & 3,70360 & 16 \\
\cline { 2 - 5 } & Auditori & $\begin{array}{r}46,0 \\
714\end{array}$ & 4,19641 & 14 \\
\cline { 2 - 5 } & Kinestetik & $\begin{array}{r}48,5 \\
455\end{array}$ & 1,05683 & 22 \\
\cline { 2 - 5 } & Total & $\begin{array}{c}46,36 \\
54\end{array}$ & 3,66236 & 52 \\
\hline \multirow{2}{*}{ Multimedia PPT } & Auditori & $\begin{array}{c}35,8 \\
182\end{array}$ & 5,89607 & 11 \\
\cline { 2 - 5 } & & 42,9 & 3,59678 & 20 \\
\hline
\end{tabular}




\begin{tabular}{ccccc}
\hline & \multicolumn{4}{c}{000} \\
\cline { 2 - 4 } & Kinestetik & $\begin{array}{c}45,4 \\
545\end{array}$ & 3,86347 & 22 \\
\cline { 2 - 5 } Total & $\begin{array}{c}42,49 \\
06\end{array}$ & 5,53528 & 53 \\
\hline \multirow{2}{*}{ Votsual } & $\begin{array}{c}40,4 \\
444\end{array}$ & 6,04683 & 27 \\
\cline { 2 - 5 } & Auditori & $\begin{array}{c}44,2 \\
059\end{array}$ & 4,11044 & \multirow{2}{*}{34} \\
\hline \multirow{2}{*}{ Kinestetik } & $\begin{array}{c}47,0 \\
000\end{array}$ & 3,20610 & \multirow{2}{*}{44} \\
\hline \multirow{2}{*}{ Total } & $\begin{array}{c}44,40 \\
95\end{array}$ & 5,06818 & 105 \\
\hline
\end{tabular}

\section{Hasil Uji Hipotesis}

Pengujian hipotesis dimaksudkan untuk menjawab tiga persoalan utama, yang akan dirumuskan kedalam dua pilihan hipotesis, yaitu penerimaan atau penolakan $\mathrm{H}_{\mathrm{o}}$ dengan taraf signifikansi 0.05 . Hasil uji hipotesis disajikan dalam analisis varian dua jalur Tabel 3 berikut:

Tabel 3: Hasil Uji Hipotesis

\begin{tabular}{lrrrrr}
\multicolumn{1}{c}{ Source } & $\begin{array}{c}\text { Type III Sum } \\
\text { of Squares }\end{array}$ & Df & $\begin{array}{c}\text { Mean } \\
\text { Square }\end{array}$ & F & \multicolumn{1}{c}{ Sig. } \\
\hline Corrected Model & $1306,366^{\text {a }}$ & 5 & 261,273 & 18,949 &, 000 \\
\hline Intercept & 188276,252 & 1 & $\begin{array}{r}188276,2 \\
52\end{array}$ & $\begin{array}{r}13654, \\
960\end{array}$ &, 000 \\
\hline Multimedia Pembelajaran & 541,197 & 1 & 541,197 & 39,251 &, 000 \\
\hline Gaya Belajar & 868,159 & 2 & 434,079 & 31,482 &, 000 \\
\hline $\begin{array}{l}\text { Multimedia Pembelajaran * Gaya } \\
\text { Belajar }\end{array}$ & 106,731 & 2 & 53,365 & 3,870 &, 024 \\
\hline Error & 1365,024 & 99 & 13,788 & & \\
\hline Total & 209753,000 & 105 & & & \\
\hline Corrected Total & 2671,390 & 104 & & & \\
\hline a. R Squared
\end{tabular}

a. R Squared $=, 489$ (Adjusted R Squared $=, 463$ )

Tabel 3 di atas menunjukkan bahwa: Pertama, ada perbedaan kemampuan mengingat konsep mata kuliah multimedia pembelajaran antara kelompok mahasiswa yang dibelajarkan menggunakan multimedia pembelajaran presentasi prezi desktop dengan kelompok mahasiswa yang dibelajarkan menggunakan multimedia pembelajaran presentasi power point pada mahasiswa Jurusan Pendidikan Teknologi Pertanian Fakultas Teknik UNM dengan nilai $\mathrm{F}=$ 39.251 yang lebih besar dari nilai $F$ tabel
$=3.92$ dan nilai probabilitas $\mathrm{p}=0.000$ yang lebih kecil dari alpha $0.05(\mathrm{p}=<$ 0.05), sehingga hipotesis nol $\left(\mathrm{H}_{\mathrm{o}}\right)$ ditolak. Kedua, ada perbedaan kemampuan mengingat konsep mata kuliah multimedia pembelajaran antara kelompok mahasiswa yang memiliki gaya belajar visual, auditori dan kinestetik pada mahasiswa Jurusan Pendidikan Teknologi Pertanian Fakultas Teknik UNM dengan nilai $\mathrm{F}=31.482$ yang lebih besar dari nilai $\mathrm{F}$ tabel $=3.92$ dan nilai probabilitas $\mathrm{p}=0.000$ yang 
lebih besar dari alpha $0.05(\mathrm{p}=>0.05)$, sehingga hipotesis nol $\left(\mathrm{H}_{\mathrm{o}}\right)$ ditolak. Ketiga, ada interaksi antara multimedia pembelajaran dan gaya belajar (visual, auditori, , dan kinestetik) terhadap kemampuan mengingat konsep mata kuliah multimedia pembelajaran mahasiswa Jurusan Pendidikan Teknologi Pertanian Fakultas Teknik UNM dengan nilai $\mathrm{F}=3.870$ yang lebih kecil dari nilai $\mathrm{F}$ tabel $=3.92$ dengan nilai probabilitas $\mathrm{p}$ $=0.024$ yang lebih kecil dari alpha 0.05 $(\mathrm{p}=<0.05)$, sehingga hipotesis nol $\left(\mathrm{H}_{\mathrm{o}}\right)$ ditolak.

Pola interaksi antara multimedia pembelajaran dan gaya belajar terhadap kemampuan mengingat konsep mata kuliah multimedia pembelajaran disajikan dalam Gambar 1 berikut:

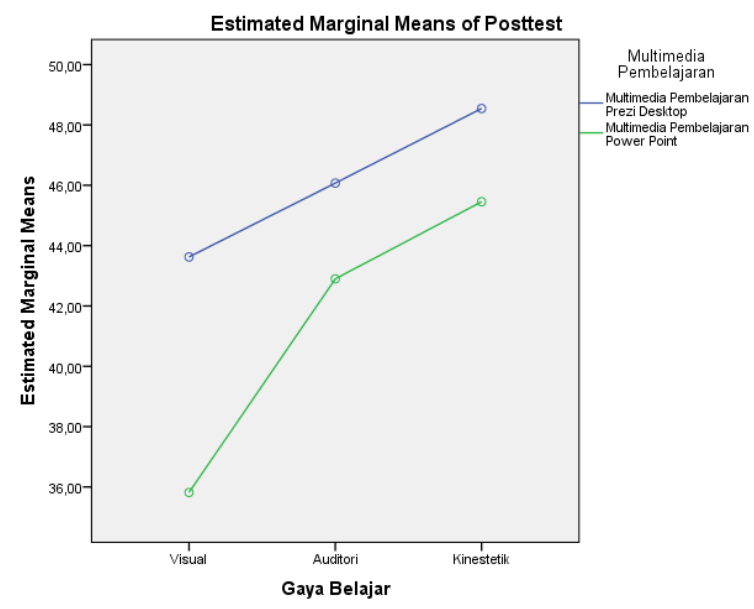

\section{Gambar 1: Pola interaksi multimedia pembelajaran dan gaya belajar terhadap kemampuan mengingat konsep}

Gambar 1 di atas menunjukkan bahwa rata-rata kemampuan mengingat konsep pada (1) kelompok multimedia presentasi prezi dan gaya belajar visual, auditori, dan kinestetik lebih besar daripada gaya belajar pada kelompok multimedia pembelajaran presentasi power point. (2) gaya belajar kinestetik adalah memiliki skor paling tinggi diantara kedua jenis gaya belajar lainnya (diikuti gaya belajar auditori lalu visual), baik pada kelompok mahasiswa yang dibelajarkan dengan multimedia presentasi prezi maupun pada multimedia presentasi power point.

\section{PEMBAHASAN}

$\begin{array}{lrr}\begin{array}{l}\text { Pengaruh } \\ \text { terhadap }\end{array} & \begin{array}{r}\text { Multimedia } \\ \text { Kemampuan }\end{array} & \begin{array}{r}\text { Pembelajaran } \\ \text { Mengingat }\end{array} \\ \text { Konsep } & & \\ \quad \text { Hasil } & \text { pengujian } & \text { hipotesis }\end{array}$ menunjukkan bahwa terdapat perbedaan kemampuan mengingat konsep mata kuliah multimedia pembelajaran antara kelompok mahasiswa yang diberi perlakuan menggunakan multimedia presentasi pembelajaran prezi desktop dengan kelompok mahasiswa yang diberi perlakuan menggunakan multimedia presentasi pembelajaran power point program studi Pendidikan Teknologi Pertanian. Hasil mean skor kemampuan mengingat konsep mata kuliah multimedia pembelajaran pada mahasiswa yang menggunakan multimedia presentasi pembelajaran prezi desktop adalah lebih tinggi dibandingkan dengan mean skor kemampuan mengingat konsep mata kuliah multimedia pembelajaran pada mahasiswa yang menggunakan multimedia presentasi pembelajaran power point.

Perbedaan mean skor kemampuan mengingat konsep mahasiswa dalam penelitian ini, mengindikasikan bahwa penggunaan multimedia presentasi pembelajaran prezi desktop memberikan pengaruh yang lebih baik terhadap kemampuan mengingat konsep dibandingkan dengan penggunaan multimedia presentasi pembelajaran power point.

Besarnya pengaruh penggunaan multimedia presentasi pembelajaran prezi desktop dibanding dengan multimedia presentasi pembelajaran power point karena multimedia presentasi pembelajaran prezi desktop lebih 
memberikan tayangan dan tampilan materi yang lebih animatif, variatif, dan kesan kanfasnya lebih hidup. Temuan penelitian ini sejalan dengan penelitian yang dilakukan oleh (Casteleyn, 2011; Rockinson, et.al, 2011; Brock \& Brodahl, 2013; Othman \& Najib, 2013), yang menjelaskan peran multimedia presentasi berbasis prezi yang dapat secara efektif meningkatkan minat, dan kreativitas, peserta didik dapat mengeksplorasi ide, dapat melihat, mengingat dan memahami sebuah konsep melalui perpindahan antara konsep, topik, dan subtopik dengan menggunakan gaya belajar visual, auditory, dan kinestetik.

Mengapa multimedia presentasi berbasis prezi lebih efektif dalam menghasilkan kemampuan mengingat konsep dibandingkan dengan multimedia presentaso berbasis power point? Beberapa penelitian menjelaskan bahwa multimedia presentasi berbasis prezi dapat meningkatkan hasil belajar, menarik perhatian dari efek zooming dan pergantian antar kanvas satu dengan yang lainnya, memberikan motivasi yang positif dan rasa ingin mencoba mengetahui lebih banyak dari materi yang akan ditayangkan (Wulandari \& Hakim, 2011; Nugraha, 2014).

Efek rasa ingin tahu dan motivasi yang tinggi dari mahasiswa menjadi modal belajar dalam menanya, menganalisis, mensintesis, dan mengembangkan kemampuan koghnitif lainnya yang lebih tinggi. Ketika setiap kanvas secara zooming ditampilkan melalui laptop, saat itu pula mahasiswa merasakan rasa ingin tahu dan merasa tertarik dengan isi dari setiap materi. Selain itu pengaturan prezi yang demikian rapinya dari satu kanvas ke kanvas berikutnya seakan memberikan kesan bahwa multimedia presentasi prezi memberikan pengaruh yang kuat dalam mendorong dan memotivasi proses belajar mengajar peserta didik.
Temuan penelitian ini dan penilitian-penilitian lain yang relevan menegaskan bahwa multimedia presentasi prezi telah memberikan pengaruh yang signifikan dalam mengakomodasi kemampuan mengingat konsep pada mata kuliah multimedia pembelajaran. Penggunaan multimedia presentasi prezi telah mununjukkan bahwa penggunaan media tersebut membuat peserta didik dapat menikmati tayangan dan tampilan penyampaian bahan dan materi oleh pengajar. Pembelajaran bermedia dalam proses belajar mengajar dapat membangkitkan keinginan dan minat yang baru, membangkitkan motivasi dan rangsangan kegiatan belajar, bahkan membawa pengaruh-pengaruh psikologis terhadap siswa. Penggunaan media pembelajaran pada tahap orientasi pembelajaran akan sangat membantu keefektifan proses pembelajaran dan penyampaian pesan serta isi pelajaran saat itu (Angkowo dan Kosasih, 2007). Belajar dengan terbiasa menggunakan media, efektif mendorong retensi belajar meningkatkan rangsangan berfikir dan mudah mengingat konsep. Media yang baik adalah media yang mudah dipahami, mudah dijalankan, dan dapat menampilkan struktur isi materi secara linear. Media seperti prezi adalah media yang memiliki ciri seperti yang dikemukakan bersifat mudah dan linear menyampaikan materi. Hal inilah menjadi bukti mengapa pembelajaran menggunakan multimedia presentasi prezi memiliki peluang yang baik bagi retensi belajar mengingat konsep objek. Hal ini terjadi karena, prezi memiliki: 1) keluasaan merancang presentasi dengan segala kreativitas dan imajinasi tanpa dibatasi oleh slide, 2) menggunakan sistem garis edar atau disebut "Path" yang digunakan untuk mengatur perpindahan dengan efek zooming antara satu objek ke objek lainnya didalam kanvas, dan 3) memberikan fasilitas untuk memasukkan gambar, video, 
beberapa shapes dan ilustrasi seperti diagram (Alwaystau, 2013)

Dalam penelitian ini pembelajaran yang disajikan lebih banyak mencakup aspek kompetensi kognitif yang lebih tinggi dan dalam cakupan kemampuan mengingkat konsep, kemampuan menyebutkan, menjelaskan, dan mengidentifikasi berbagai konsep dari setiap materi yang disajikan. Dengan demikian penggunaan multimedia presentasi prezi sudah sesuai dengan karakteristik mata kuliah multimedia pembelajaran pada aspek dasar-dasar teori media pembelajaran.

\section{Pengaruh Gaya Belajar terhadap Kemampuan Mengingat Konsep}

Gaya belajar secara teori dapat dikatakan memiliki potensi dalam memperoleh hasil belajar. Gaya belajar yang dimiliki peserta didik diyakini mampu mengarahkan peserta didik dalam mempelajari materi pelajaran. Ini juga sekaligus menjadi modal bagi peserta didik untuk belajar mentransformasi pengetahuan yang oleh DePorter (2004) disebut sebagai modalitas belajar yang meliputi tiga tipe gaya belajar, yaitu gaya belajar visual, gaya belajar auditori, dan gaya belajar kinestetik.

Gaya belajar visual, auditori, dan kinestetik diyakini dapat berpengaruh terhadap kemampuan mengingat konsep materi. Adakalanya mahasiswa yang memiliki gaya belajar visual unggul dalam kemampuan mengingat konsep pada mata pelajaran tertentu. Demikian halnya adakalanya mahasiswa yang memiliki gaya belajar auditori unggul dalam kemampuan mengingat konsep pada mata pelajaran tertentu, dan juga gaya belajar kinestetik bisa unggul dalam kemampuan pada mata pelajaran lain yang memiliki ciri dan karakteristik mata pelajaran yang sesuai dengan jenis gaya belajar yang dimiliki peserta didik.

Mahasiswa bergaya belajar visual, memiliki karakteristik: 1) mengandalkan pandangan mata sebagai pusat penangkapan informasi, mengamati, mengobservasi, dan menunjukkan objek, 2) mengandalkan warna, catatan, visualisasi gambar, dan pergerakan animasi yang dinamis, dan 3) lebih senang membaca dibanding mendengar seseorang yang berbicara, termasuk ketika guru mengajar lebih senang membaca materi yang dipelajari daripada menulis (DePorter, 2004; Mayer, 2009; Gilakjani, 2012). Mahasiswa atau peserta didik yang senang dengan gaya belajar visual akan senantiasa lebih mudah mengolah informasi melalui pemetaan bacaan, grafik, gambar, dan objek lainnya untuk ditransformasikan kedalam suatu kalimat konseptual yang lebih bermakna dan lebih mudah diingat. Materi multimedia pembelajaran lebih banyak disajikan dalam bentuk teori dan konsep. Untuk lebih memudahkan peserta didik mengingat dan memahamainya, pendekatan media secara visual adalah dengan memperlihatkan gambar-gambar yang nyata dan lebih kreatif sesuai peta pikiran yang dikandung dari konsep teori multimedia pembelajaran. Menurut Vaishnav (2013), pendekatan mengajar yang dapat dilakukan bagi pebelajar yang memiliki gaya belajar visual adalah belajar sambil menampilkan kata, grafik dan gambar. Ini cukup memberikan kesan mendalam yang meungkinkan pebelajar dapat kuat mengingat konsep dari suatu objek.

Berbeda dengan gaya belajar auditori, pebelajar yang masuk dalam kelompok gaya belajar auditori memiliki kecenderungan belajar sambil mendengar. Gaya belajar auditori memberikan rasa nyaman belajar terhadap media yang menampilkan suara, musik, dan ceramah, diskusi yang menampilkan debat terbuka, langsung, disertai feed back. Pebelajar dengan gaya belajar auditori mengandalkan telinga sebagai indera pendengar sekaligus penstimulasi respon utama ketika 
mendengar pertama kali informasi. Olehnya itu menurut Vaishnav (2013), pebelajar auditori, pertama kali menyimak melalui pendengaran dan membaca pesan dari pembelajar (guru). Sedangkan gaya belajar kinestetik mengkondisikan rasa nyaman belajar bagi kelompok siswa apabila belajar dengan melakukan langsung, terlibat mengerjakan dan merasakan atau mencoba hal-hal yang sedang dipelajari. Dalam istilah belajar, tipe pebelajar kinestetik disebut learning by doing atau belajar sambil melakukan, belajar secara aktif, menggunakan fisik seperti tangan (Gilakjani \& Ahmadi, 2011; Vaishnav, 2013).

Baik gaya belajar visual, maupun gaya belajar auditori dan kinestetik memiliki hubungan yang signifikan dalam memberikan pengalaman belajar memecahkan masalah bagi peserta didik. Dijelaskan oleh Bagheri \& Gholami (2013), yang meneliti sejumlah mahasiswa di Universitas Azad Kairo, bahwa gaya belajar visual, auditori, dan kinestetik (VAK, secara signifikan memberikan kontribusi yang positif dan signifikan dalam mentransformasi gaya mahasiswa ketika belajar memecahkan masalah. Modalitas gaya belajar VAK, bisa saja tidak sepenuhnya dimiliki oleh peserta didik, adakalanya hanya visual kinestetik (VK) saja, atau auditori kinestetik (AK) saja, atau auitori visual (AV) saja, yang menurut Ariffin (2013), salah satu atau keduanya atau ketiganya memiliki hubungan dalam perolehan hasil belajar.

Temuan dalam penelitian ini sejalan dengan hipotesis statistik yang dibangun yang menyatakan bahwa terdapat perbedaan kemampuan mengingat konsep antara kelompok mahasiswa yang memiliki gaya belajar visual, auditori, dan kinestetik sesuai dengan ekspektasi peneiliti. Ekspektasi ini didasari oleh pengetahuan teori dan hasil penelitian yang ada sebelumnya.
Uraian tentang definisi dan karakteristik gaya belajar memberikan pemahaman bahwa gaya belajar merupakan karakteristik individu pebelajar yang khas yang berbeda antara individu bergaya belajar visual, gaya belajar auditori, dan gaya belajar kinestetik. Perbedaan keempat gaya belajar tersebut berimplikasi pada perbedaan individu dalam mengelola, memproses, mempelajari dan memecahkan masalah-masalah pengetahuan. Cara-cara individu memproses informasi dan menggunakan strategi-strategi, dan memecahkan masalah dari tugas-tugas yang diberikan berbeda sesuai dengan gaya belajar yang dimiliknya. Perbedaan jenis gaya belajar akan memberikan perbedaan individu secara konseptual dalam mengelola pengetahuan yang dipelajarinya.

\section{Pengaruh Interaksi antara Multimedia Pembelajaran dan Gaya Belajar terhadap Kemampuan Mengingat Konsep}

Interaksi dalam penelitian memberikan kajian yang bertujuan memberikan adanya keterkaitan beberapa variabel prediktor dengan variabel yang diprediksi. Pengaruh interaksi dalam suatu penelitian merupakan pengaruh bersama dua atau lebih dari variabel bebas terhadap variabel tidak bebas (Kerlinger, 2000; Ghozali, 2009).

Hasil pengujian hipotesis terkait ada tidaknya interaksi antara multimedia pembelajaran dan gaya belajar terhadap kemampuan mengingat konsep materi kuliah multimedia pembelajaran menunjukkan nilai $\mathrm{p}=0.024(\mathrm{p}<0.05)$. Artinya, bahwa terdapat interaksi antara multimedia pembelajaran dan gaya belajar terhadap kemampuan mengingat konsep mata kuliah multimedia pembelajaran.

Interaksi terjadi bila variabelvariabel bebas tidak membawa akibat- 
akibat secara terpisah dan sendiri-sendiri. Dalam penelitian ini diperoleh pengaruh utama (main effect) secara bersam-sama memberi pengaruh terhadap variabel independen. Menurut Kerlinger (2000), interaksi ini terjadi karena dipengaruhi satu dari tiga penyebab interaksi, yaitu interaksi terjadi karena efek dari satu tingkat eksperimen semata, namun tidak dari eksperimen lainnya.

Pola interaksi yang ditemukan dalam penelitian ini menunjukkan bahwa baik multimedia presentasi prezi maupun multimedia power point, mahasiswa yang bergaya belajar kinestetik memiliki kemampuan mengingat konsep yang lebih tinggi dibanding mahasiswa yang bergaya belajar auditori, maupun kinestetik. Selanjutnya mahasiswa yang bergaya belajar auditori memiliki kemampuan mengingat konsep yang lebih tinggi dibanding mahasiswa yang memiliki gaya belajar visual. Kemampuan mengingat konsep dimiliki oleh mahasiswa yang bergaya belajar visual. Temuan ini terjadi baik pada kelompok mahasiswa yang dibelajarkan dengan multimedia presentasi prezi maupun kelompok mahasiswa yang dibelajarkan dengan multimedia presentasi power point.

\section{KESIMPULAN DAN SARAN Kesimpulan}

Berdasarkan pengujian hipotesis, dan pembahasan hasil penelitian, beberapa kesimpulan dapat dikemukakan sebagai berikut:

Terdapat perbedaan kemampuan memahami konsep pada matakuliah multimedia pembelajaran antara kelompok mahasiswa yang dibelajarkan dengan menggunakan multimedia presentasi prezi dengan kelompok mahasiswa yang dibelajarkan dengan menggunakan multimedia presentasi power point pada mahasiswa program studi Pendidikan Teknologi pertanian. Penggunaan multimedia pembelajaran berbasis presentasi prezi memberikan perolehan kemampuan mengingat konsep yang lebih baik dibanding menggunakan multimedia presentasi power point. Hal ini terjadi selain karena adanya dukungan teori dan hasil penelitian juga karena penggunaan multimedia presentasi berbasis prezi memberikan efek kemenarikan dari sisi pendekatan multimedia. Penggunaan multimedia presentasi prezi dapat mengakomodasi kemampuan kognitif pada level mengingat, mengetahui, dan memahami. Dengan demikian, jenis penggunaan multimedia presentasi prezi itu lebih sesuai diajarkan pada level pengetahuan mengingat, mengetahui, dan memahami dibanding dengan menggunakan multimedia presentasi power point.

Terdapat perbedaan kemampuan memahami konsep matakuliah multimedia pembelajaran antara kelompok mahasiswa yang memiliki gaya belajar visual, auditori, dan kinestetik pada mahasiswa jurusan Pendidikan Teknologi Pertanian. Secara teoretis dan berdasarkan temuan penelitian telah menunjukkan bahwa terdapat perbedaan prestasi belajar diantara individu yang bergaya belajar visual, auditori, dan kinestetik. Perbedaan gaya belajar tersebut akan memberikan pengaruh yang berbeda terhadap kemampuan belajar. Mengingat sifat dan materi matakuliah multimedia pembelajaran sesuai dengan karakteristik mahasiswa yang bergaya belajar kinestetik, auditori, maupun visual, maka diharapkan terdapat perbedaan kemampuan dalam mengingat antara mahasiswa yang bergaya belajar visual, auditori, dan kinestetik.

Terdapat interaksi antara multimedia pembelajaran presentasi prezi dan gaya belajar terhadap kemampuan mengingat konsep matakuliah multimedia pembelajaran pada mahasiswa jurusan Pendidikan Teknologi Pertanian FT UNM. Interaksi antara dua variabel 
secara bersama-sama mempengaruhi kemampuan mengingat dan memahami konsep. Interaksi ini tergolong interaksi tidak signifikan, hal ini terjadi karena salah satu multimedia pembelajaran presentasi yang diduga lebih kuat pengaruhnya dirasakan oleh mahasiswa sebagai media belajar yang sudah lebih dulu mempengaruhi karakteristik mahasiswa sebelum eksperimen dilakukan. Untuk itu, perlu mempertimbangkan penelitian lebih lanjut dengan mengontrol variabel multimedia pembelajaran yang digunakan

\section{Saran}

Sebagai upaya pemanfaatan temuan hasil penelitian penggunaan multimedia pembelajaran dalam penelitian, diajukan saran-saran sebagai berikut: Berdasarkan temuan dalam penelitian ini, penggunaan multimedia presentasi berbasis prezi sebagai multimedia yang full kreasi dan inovasi melahirkan rasa ingin tahu. Untuk itu perlu diintegrasikan penggunaan multimedia presentasi prezi sebagai alternatif penggunaan jenis media presentasi dalam memberikan materi mata kuliah.

Penelitian dengan memilih jenis gaya belajar selain modalitas belajar (VAK), perlu dilakukan. Hal ini untuk melihat sejauh mana gaya belajar dari sudut pandang teori gaya belajar lain dapat berkontribusi terhadap kemampuan mengingat konsep.

Perlu menyeleksi materi yang akan disajikan dalam multimedia peresentasi prezi. Jika hendak menggunakan media prezi sebagai media presentasi, agar memperhatikan sifat dan karakteristik materi atau kompetensi dasar yang akan diajarkan.

\section{DAFTAR PUSTAKA}

Anderson \& Krathwohl. 2010. Pembelajaran, Pengajaran, dan Asesmen. Yogyakarta: Pustaka Pelajar

Angkowo R dan A Kosasih, 2007, Optimalisasi Media Pembelajaran, Jakarta: PT Grasindo.

Alwaystau, Hadmin. 2013. Prezi, Buat Presentasi Lebih Menarik. Diakses tanggal 18 Oktober 2014. di http://alwaystau.blogspot.com/2013 /04/prezi-buat-presentasi-lebihmenarik.html

Ariffin, Izyana. 2013. Learning Style and Course Performance: an Empirical Study of Uniten it Students. International Journal of Asian Social Science. Vol 4 No.2. Halaman 208-216. http://www.aessweb.com/journals/5 007. Diakses tanggal 12 Oktober 2014.

Bagheri, Mohammad, S. \& Gholami, Shahin. 2013. Relationship Between VAK Learning Styles and Problem Solving Styles Regarding Gender and Students' Fields of Study. Journal of Language Teaching and Research, Vol. 4, No. 4, Halaman. 700-706. July 2013

Brock, Sabra \& Brodahl, Cornelia. 2013. A Tale of Two Cultures: Cross Cultural Comparison in Learning the Prezi Presentation Software Tool in the US and Norway. Journal of Information Technology Education Research. Vol. 12 Tahun 2013, Hal 1-25.

Casteleyn, J., Mottart, A. \& Valcke, M. 2011. Power Point vs. Prezi - The impact of graphic organizers on 
learning from presentations. To be published in Technology, Pedagogy \& Education. Diakses di http//www: www.academia.edu. Tanggal 8 Oktober 2014.

DePorter. Bobbi. dkk. 2002. Quantum Teaching: Orchestrating Student Succes. Bandung: Kaifa

DePorter, Bobbi \& Hernacki. Mike. . 2004. Quantum Learning : Membiasakan Belajar Nyaman dan Menyenangkan. Bandung : Kaifa

Enterprise, Jubilee. 2012. Inspiring Presentation. Jakarta: Elex Media Komputindo

Felder. R.M. \& R. Brent. 2005. Journal Engineering. Education. Understanding Student Differences. An exploration of differences in student learning styles, approaches to learning (deep, surface, and strategic), and levels of intellectual development, with recommended teaching practices to address all three categories. 94(1). 57-72

Gall, M.D., Gall, J.P., \& Borg, W. R. 2003. Educational research: An Introduction. Seventh Edition. Boston: Pearson Education,Inc.

Ghozali, I. 2009. Aplikasi Analisis Multivariate dengan Program SPSS. Semarang: Badan Penerbit Universitas Diponegoro.

Gilakjani \& Ahmadi. 2011. Paper title: The Effect of Visual, Auditory, and Kinaesthetic Learning Styles on Language Teaching. International Conference on Social Science and Humanity. IPEDR Vol.5 2011. http://www.ipedr.com/vol5/no2/104 -H10249.pdf. Diakses tanggal 12 Oktober 2014.
Gilakjani, Abbas, Pourhossein. 2012. Visual, Auditory, Kinaesthetic Learning Styles and Their Impacts on English Language Teaching. Journal of Studies in Education ISSN 2162-6952. 2012, Vol. 2, No. 1. Halaman 104-113.

Gunawan, Adi W. 2004. Genius Learning Strategy: Petunjuk Praktis Untuk Menerapkan Accelerated Learning. Jakarta: Gramedia Pustaka Utama.

Kerlinger, F. N. 2000. Asas-Asas Penelitian Behavioral. Edisi 3 Cetakan 7. Yogyakarta: Gajah Mada University Press.

Kusrianto. Adi. 2013. Business Presentation. Elex Media Komputindo Kompas Gramedia:Jakarta

Mayasari, Eny. 2012. Pengaruh Penggunaan Buku Ajar Ikatan Ikonik dengan Pendekatan Multiprestase Terhadap Prestasi Belajar Siswa. Skripsi Universitas Tanjungpura. Jurusan Kima Fakultas FKIP: Pontianak

Mayer E. R. 2009. Multimedia Learning. Pustaka Pelajar: Jogjakarta

Munir. 2013. Multimedia: Konsep \& Aplikasi dalam Pendidikan. Alfabeta: Bandung

Nugraha, Ismail. 2014. Pengaruh Multimedia prezi Desktop terhadap Hasil Belajar Peserta Didik pada Mata Pelajaran Sosiologi. repository.upi.edu/7012/7/S_KTP_ 0906566_Tittle.pdf. diakses tanggal 15 Oktober 2014.

Othman \& Najib, 2013. Problem Solving In Thermodynamics: Animation In 
Animated Mind Mapping. International Journal of Education and Research. Vol. 1 No. 9 September. Hal 1-12

Prasetya, dkk. 2008. Pengaruh Penggunaan Media Pembelajaran Berbasis Komputer dengan Pendekatan Chemo-Edutainment Terhadap Hasil Belajar Kimia Siswa. Jurnal Inovasi Pendidikan Kimia, Vol. 2. 2008. Hal. 287-293. FMIPA Universitas Negeri Semarang.

Reiber, Lloyd P. (1999). Animation in Computer-Based Instruction. Educational Technology Research and Development, 38 (1), 77-86.

Rockinson, et.al,. 2011. Prezi: Trading Linear Presentations for Conceptual Learning Experiences in Counselor. SelectedWorks. Retrieved from: http://works.bepress.com/amanda_r ockinson_szapkiw/18

Salkind, J. Neil. 2006. Exploring research: Sixth Edition. New Jersey: Prentice Hall.

Smaldino, S.E., Russel, J.D., Heinich, R., \& Molenda, M. (2005). Instructional Technology and Media for Learning. 8th Edition. Upper Saddle River, NJ: Pearson Education, Inc.

Sugiyono. 2008. Statistik untuk Penelitian. Cetakan ke 13. Bandung: CV Alfabeta.

Tuckman, W. B. 1999. Conducting Educational Research: Second Edition. USA: Harcourt Brace Jovanovich, Publisher.

Vaishnav, Rajshree, S. 2013. Learning Style And Academic
Achievement Of Secondary School Students. Voice of Research, Vol. 1 Issue 4, March 2013, ISSN No. 2277-7733

Vockell, Edward L. \& Asher, J W. 1995. Research Educational. New Jersey Ohio: Merrill an Imprint of Prentice Hall.

Winarsunu, T. 2006. Statistik dalam Penelitian Psikologi dan Pendidikan. Malang: Universitas Muhammadiyah Malang Pres.

Wulandari, Ayu, Novita \& Hakim, Lukman. 2011. Perbandingan Hasil Belajar Siswa Melalui Media Pembelajaran Prezi dengan Powerpoint pada Mata Diklat Akuntansi. ejournal.unesa.ac.id/article/12095/5 2/article.pdf. diakses tanggal 15 Oktober 2014. 